\title{
核酸およびアミノ酸誘導体を中心とした有機 合成プロセスの開発
}

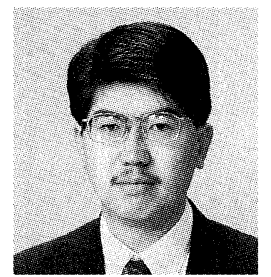

大西 智之

Tomoyuki Onishi

キーワード：核酸，アミノ酸，抗ウイルス剤，プロセス開発，医薬中間体

はじめに

核酸系抗ウイルス剤がヘルペス，水痘，带状疮疹，工 イズなどの画期的治療薬となったのを嚆矢として，現 在，核酸誘導体は医薬品の中でユニークな位置を占めて いる。一方，アミノ酸誘導体も $\mathrm{ACE}$ 阻害剂や各種のプ ロテアーゼ阻害剤等が既に開発されて来ており，これま た医薬品の中でも重要な存在となっている。

これら核酸誘導体，アミノ酸誘導体の出発原料として は，それぞれ核酸，アミノ酸を用いるのが 1 つの自然な 発想であり，また合成効率上も好ましいと思われる。し かしながら，これらから種々の誘導体を合成するのは必 ずしも単純ではなく，何らかのブレイクスルーを必要と することも多い。本稿では筆者が味の素(株)に入社して 以来，携わった核酸誘導体㧍よびアミノ酸誘導体のプロ セ又開発について紹介しつつ，有機合成プロセス開発の 何が面白いかについて考えてみたい。

\section{1. ヌクレオシド系抗ヘルペス剤 A-5021 の合成プロセ スの開発 ${ }^{11}$}

A-5021(1)は味の素で創楞された強力な抗へル几゚，ス、活 性を有するヌクレオシドである。探索段階では，マロン 酸エステルと光学活性エピクロロヒドリン 2 のアルキル 化反応によって得られる光学活性シクロプロパンラクト ン 3 を鍵化合物とし，水酸基の保護，脱保護を繰り返し て合成していた。これは特にプリン塩基のアルキル化に 用いるシクロプロピルメチルスルホナートやハライドが
不安定で，保護基を付け替えて安定化させる必要があっ たためである。しかしながら，A-5021を大量に合成す ることを考えると，この方法は工程も長く収率も良くな い。そこで,より効率的なルートを求めて, 検討を行った。

スキーム 1 に-5021の実用的新合成プロセス（開発 初期の段階のもの)を示す。ルート短縮のポイントとし ては次の 2 点が考えられた。すなわち，1)ラクトン環を ジオール保護体と考元最後に還元する，また2)ラクト ン環より先にエチルエステル部分を還元して，アルキル 化に用いるということである。シクロプロパンラクトン のラクトン部分は歪みのため反応性に富んで扔り，加水 分解や還元を受けやすい。実際に 3 に1等量のアルカリ をエタノール中で作用させるとラクトン部分のみを開裂 させることができた。この状態で引き続き，加熱還流 下， $\mathrm{NaBH}_{4}$ 還元を行うと，エステル部分のみを還元し てラクトンアルコール 4 を得ることができた。4は脱離 基導入後も比較的安定であり，そのメシラート 5 は単離 してアルキル化反応に用いることができた。ラクトン基 が不安定なシタロプロピル,メチルスルホナートの安定化 に寄与しているものと考えられる。アルキル化に際して はここでは 2-アミノー6-クロロプリンを用いた。アル キル化の 9 位 $/ 7$ 位の選択性は 6.5-7:1 程度であり, ク ロマトグラフィーにより容易に両者の分離が可能であっ た。アルキル化体 6 を $80 \%$ ギ酸中，加熱してラクトン グアニン 7 とし，これをエタノール中， $\mathrm{NaBH}_{4}$ で還元

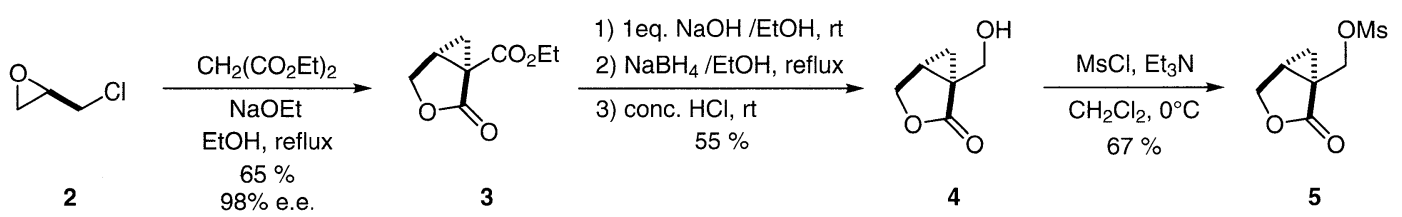

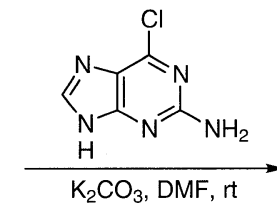

$78 \%$

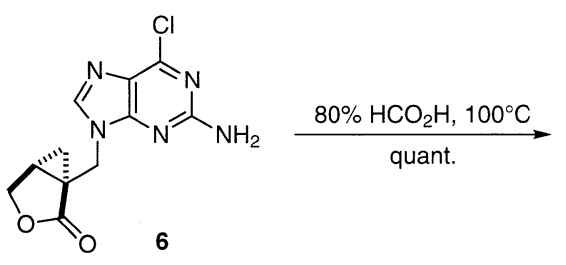<smiles>Nc1nc2c(ncn2CC2CCCO2)c(=O)[nH]1</smiles><smiles>CCCCCC(CO)Cn1cnc2c(=O)[nH]c(N)nc21</smiles>

Scheme 1 A practical synthesis of antiviral cyclopropane nucleoside A-5021. 
<smiles>CC(=O)C(Cc1ccccc1)NCl</smiles>

10

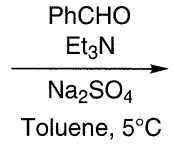

$94 \%$

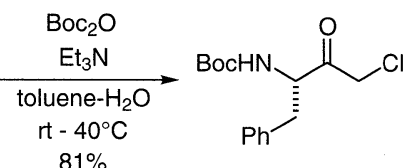

$81 \%$

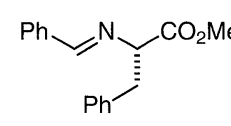

11

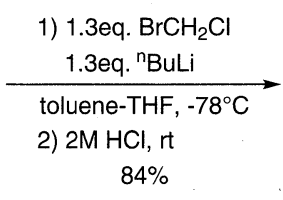

$84 \%$<smiles>O=CN[C@@H](Cc1ccccc1)C(=O)CCl</smiles>

$12(>98 \%$ e.e.)

9

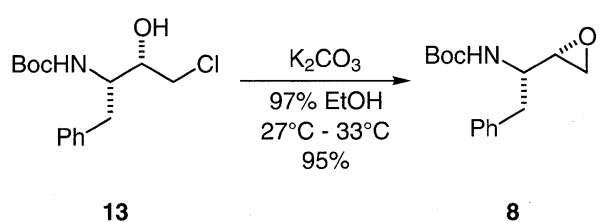

Scheme 2 A practical synthesis of 8, the key intermediate of HIV protease inhiditors.

すると，目的物 A-5021(1)が良い収率で得られた。

こうして, 全く保護基を用いることなく, 短工程で A-5021を合成するルートが見いだせた。この方法は， 高価な試薬や特殊な条件を使うこともないため，工業的 生産にも十分適用可能である。

\section{HIV プロテアーゼ阻害剂の鍵中間体の合成プロセス の開発 2 (2)}

エポキシド 8 は HIV プロテアーゼ阻害剂の沉用中間 体として重要な位置を占める化合物である。このものの 製法を開発する上で最大の課題はクロロメチルケトン 9 をいかに製造するかということであり，エポキシド８は 9 の $\mathrm{NaBH}_{4}$ を用いたジアステレオ選択的還元，および 続くエポキシ化より調製可能と考えられる。我々はコス 卜競争力のあるプロセスを開発するに当たって，有機金 属試薬に対する原材料費を極小化することをコンセプト とし，まず $\mathrm{ClCH}_{2} \mathrm{Li}$ （比較的安価な ${ }^{n} \mathrm{BuLi}$ と $\mathrm{BrCH}_{2} \mathrm{Cl}$ により in situで調製) によるクロロメチル化が適応可 能な, $\mathrm{H}-\mathrm{Phe}$-OMe のアミノ基の保護基に関してスク リーニングを行った。

最初にBoc-Phe-OMe に対して $\mathrm{ClCH}_{2} \mathrm{Li}$ を作用させ て直接的に 9 を得る検討を行ったが，用いる試薬の量を 増やしても収率は $50 \%$ 以上には向上しなかった。検討 を進めていく内に，アミノ基をベンゾフェノンイミン型 保護基によって保護した化合物がクロロメチル化の有用 な基質であり，1.3 当量の $\mathrm{ClCH}_{2} \mathrm{Li}$ を作用させることに よって, 定量的に高い光学純度を有するクロロメチルケ トンが得られることを見いだした。

さらに検討を行った結果，最終的にアミノ基を安価な ベンズアルデヒドで保護した化合物である 11 のクロロ メチル化を行い，次いで塩酸で加水分解することによっ て，イミンに対する副反応やラセミ化を伴うことなく， 良好な収率で 12 が得られることを見いだした。本知見 を元に開発されたエポキシド 8 の実用的合成プロセスを スキーム 2 に示す。

こうして，工業化可能なエポキシド８の合成プロセス を見いだせた。また，本プロセスはパイロットプラント
製造を実施して，実際にスケールアップ可能であること が実証できた。

\section{おわりに}

以上，核酸誘導体およびアミノ酸誘導体のプロセス開 発について，それぞれ1例ずつ紹介した。ところでプロ セス開発は, 大学等の研究機関における学術的な研究 や, また企業内でも医薬品探索研究などと比べて, 時に 面白さ, 創造性に欠けた無味乾燥なものと評価される場 合が多いように思う。実際，コスト的な問題や他社の特 許等により，実施できることが自ずから制約されるケー スも多いのは事実である。しかしながら，これらの制約 を承知した上で新規プロセスの探索を行うことは決して 単純作業ではなく，むしろ制約があるがゆえに，より本 質を理解した上でのコンセプト造りや創意工夫を必要と するように感じる。現在でも工業的かつ経済的に実施可 能な合成手法はまだ限られており，この観点で有用な手 法を創出していくことが求められる。さらに，例え新規 ラボプロセスを見いだすことができたとしても，それを 工業化するためには, 試行錯誤しつつそれぞれの個性に 合わせた tailor made のプロセスをよく考えて開発して いくことが重要である。

我々プロセスケミストとしては仕事の性質上, first synthesis を目指すことはできない。しかしながら，合 成プロセスとしての決定版 final synthesis を目指すこと ができるのは大いにやりがいがあるものと感じている。

\section{文 献}

1) T. Onishi, T. Matsuzawa, S. Nishi, T. Tsuji, Tetrahedron Lett.,40,8845(1999)

2）大西智之, 中野敬, 廣瀬直子, 中沢正和, 井澤邦輔, 国際出 願 WO 00/44706

(2001 年 2 月 2 日受理)

\section{PROFILE}

大西智之 味の素(株)アミノサイエンス研究所ファインプロセス研究部 ケミカルプロセス研究室研究員

〔経歴〕1990 年東京大学理学部化学科卒, 1992 年同理学系研究科修士課 程修了, 同年味の素(株) 入社, 中央研究所に勤務。1998 年より現職。 〔専門〕有機合成プロセスの開発。〔連絡先〕 